\title{
A biogeographic framework of octopod species diversification: the role of the Isthmus of Panama
}

\author{
Francoise D Lima ${ }^{\text {Corresp., } 1}$, Jan M Strugnell ${ }^{2}$, Tatiana S Leite ${ }^{3}$, Sergio MQ Lima ${ }^{1}$ \\ ${ }^{1}$ Department of Botany and Zoology, Universidade Federal do Rio Grande do Norte, Natal, Rio Grande do Norte, Brazil \\ ${ }^{2}$ Centre for Sustainable Tropical Fisheries and Aquaculture, James Cook University of North Queensland, Townsville, Queensland, Australia \\ 3 Department of Ecology and Zoology, Universidade Federal de Santa Catarina, Florianópolis, Santa Catarina, Brazil \\ Corresponding Author: Francoise D Lima \\ Email address: francoisedl@yahoo.com.br
}

The uplift of the Isthmus of Panama (IP) created a land bridge between Central and South America and caused the separation of the Western Atlantic and Eastern Pacific oceans, resulting in profound changes in the environmental and oceanographic conditions. To evaluate how these changes have influenced speciation processes in octopods, fragments of two mitochondrial (Cytochrome oxidase subunit I, COI and 16S rDNA) and two nuclear (Rhodopsin and Elongation Factor-1 $\alpha$, EF-1 $\alpha$ ) genes were amplified from samples from the Atlantic and Pacific oceans. One biogeographical and four fossil calibration priors were used within a relaxed Bayesian phylogenetic analysis framework to estimate divergence times among cladogenic events. Reconstruction of the ancestral states in phylogenies was used to infer historical biogeography of the lineages and species dispersal routes. The results revealed three well-supported clades of transisthmian octopus sister species pair/complex (TSSP/TSSC) and two additional clades showing a low probability of species diversification, having been influenced by the IP. Divergence times estimated in the present study revealed that octopod TSSP/TSSC from the Atlantic and Pacific diverged between the Middle Miocene and Early Pliocene (mean range $=5-18 \mathrm{Ma}$ ). Given that oceanographic changes caused by the uplift of the IP were so strong as to affect the global climate, we suggest that octopod TSSP/TSSC diverged because of these physical and environmental barriers, even before the complete uplift of the IP $3 \mathrm{Ma}$, proposed by the Late Pliocene model. The results obtained in this phylogenetic reconstruction also indicate that the octopus species pairs in each ocean share a recent common ancestor from the Pacific Ocean. 
1 A Biogeographic Framework of Octopod Species

2 Diversification: The Role of the Isthmus of Panama

3

4

5

6

\section{Françoise D. Lima ${ }^{1}$, Jan M. Strugnell ${ }^{2}$, Tatiana S. Leite ${ }^{3}$, Sergio M. Q. Lima ${ }^{1}$}

1. Department of Botany and Zoology, Universidade Federal do Rio Grande do Norte, Natal, RN, Brazil

2. Centre for Sustainable Tropical Fisheries and Aquaculture, James Cook University of North Queensland, Townsville, Queensland, Australia

3. Department of Ecology and Zoology, Universidade Federal de Santa Catarina, Florianópolis, SC, Brazil

\section{Corresponding Author:}

Françoise Lima

Campus Universitário, Natal, RN, 59078-900, Brazil.

Email address: francoisedl@yahoo.com.br

\section{Abstract}

The uplift of the Isthmus of Panama (IP) created a land bridge between Central and South America and caused the separation of the Western Atlantic and Eastern Pacific oceans, resulting in profound changes in the environmental and oceanographic conditions. To evaluate how these changes have influenced speciation processes in octopods, fragments of two mitochondrial (Cytochrome oxidase subunit I, COI and 16S rDNA) and two nuclear (Rhodopsin and Elongation Factor-1 $\alpha$, EF-1 $\alpha$ ) genes were amplified from samples from the Atlantic and Pacific oceans. One biogeographical and four fossil calibration priors were used within a relaxed Bayesian phylogenetic analysis framework to estimate divergence times among cladogenic events. Reconstruction of the ancestral states in phylogenies was used to infer historical biogeography of the lineages and species dispersal routes. The results revealed three wellsupported clades of transisthmian octopus sister species pair/complex (TSSP/TSSC) and two additional clades showing a low probability of species diversification, having been influenced by the IP. Divergence times estimated in the present study revealed that octopod TSSP/TSSC from the Atlantic and Pacific diverged between the Middle Miocene and Early Pliocene (mean range $=$ 5-18 Ma). Given that oceanographic changes caused by the uplift of the IP were so strong as to affect the global climate, we suggest that octopod TSSP/TSSC diverged because of these physical and environmental barriers, even before the complete uplift of the IP $3 \mathrm{Ma}$, proposed by the Late Pliocene model. The results obtained in this phylogenetic reconstruction also indicate that the octopus species pairs in each ocean share a recent common ancestor from the Pacific Ocean. 
39 Keywords: phylogeny, vicariance, dispersal, speciation, fossil calibration, octopus, Isthmus of

40 Panama

41

42

Introduction

The formation of the Isthmus of Panama (IP) caused profound changes in environmental and oceanographic conditions (Haug \& Tiedemann, 1998; Bartoli et al., 2005; Schneider \& Schmittner, 2006), which influenced dispersal and speciation processes in terrestrial and marine biota (Lessios, 1981; Knowlton \& Weigt, 1998; Leigh, O’Dea, \& Vermeij, 2013). The closure of the connection between the Atlantic and Pacific oceans is considered the most important vicariant event of the Cenozoic (O'Dea et al., 2016), providing a remarkable system to study evolutionary processes in a natural environment.

The age of the final closure of the IP, as well as its role in fundamental evolutionary processes is controversial (Stone, 2014), and two hypotheses were proposed to describe this event: the Late Pliocene and the Middle Miocene models. Using geological, fossil and molecular data, several authors have proposed that the final closure of the isthmus was in the Late Pliocene, approximately 2.5-3.5 millions years ago (Ma) (Coates et al., 1992; Bartoli et al., 2005; Schneider \& Schmittner, 2006; Coates \& Stallard, 2013; O’Dea et al., 2016). However, recent studies based on dispersal waves of terrestrial organisms and geochronological information have suggested that the closure of the this seaway occurred during the Miocene (15 Ma) (Bacon et al., 2015; Hoorn \& Flantua, 2015; Montes et al., 2015).

According to the Late Pliocene hypothesis, this long process initiated with a collision of Central and South America about 15-24 Ma ago and the formation of a volcanic arc, around the Early Miocene (Coates \& Stallard, 2013). During the Middle Miocene (around $10 \mathrm{Ma}$ ), successive collisions caused widespread shallowing of the oceans and major changes of oceanic conditions, and deep and intermediate water exchanges between the Atlantic and Pacific were closed (Coates et al., 2004; Keigwin, 1982). Around 6-4 Ma oceanic conditions, including temperature, salinity, sedimentary carbon content and habitat availability on each side of the isthmus changed substantially (Haug \& Tiedemann, 1998; Leigh, O’Dea \& Vermeij, 2013). By 3 Mya, the uplift of the IP completely separated the waters of the Tropical Western Atlantic and the Tropical Eastern Pacific (Coates \& Stallard, 2013; O’Dea et al., 2016).

Studies based on Uranium-lead geochronology in detrital zircons in the Andes,

Panamanian fluvial deposits and inferences on terrestrial and aquatic dispersal provide a different insight for the early closure of the IP; the Middle Miocene hypothesis (Montes et al., 2012; Bacon et al., 2013; Bacon et al., 2015; Montes et al., 2015). In this approach, the isthmus formation started around 38-28 Ma, and the collision between the southern tip of Central America and South America occurred during the Late Oligocene (28.1-23.0 Ma). Montes et al. (2015) suggested that the complete closure interrupting the water connection between the Eastern Pacific and Western Atlantic occurred around 14-15 Ma.

The timing of the uplift of the IP, based mainly on the Late Pliocene hypothesis, is widely 77 
geological events for calibrating molecular clocks (Lessios, 2008; Parham et al., 2012; Gleadall, 2013). However, to evaluate the influence of the final seaway closure on divergence and distribution of Atlantic and Pacific sister species, it is important to use a calibration independent of the isthmus formation to avoid circular reasoning in the divergence time interpretation (Marko, 2002; O'Dea et al., 2016). Therefore, molecular phylogenies containing sister species from each side of the IP have been calibrated using the fossils record and/or the molecular evolutionary rate of a particular gene (e.g., Bermingham \& Lessios, 1993; Knowlton et al., 1993; Collins, 1996; Bartoli et al., 2005; Bacon et al., 2013; Galván-Quesada et al., 2016).

The emergence of geographical barriers, such as the formation of the Isthmus of Panama, may reduce or interrupt gene flow between populations. The vicariant populations can evolve different genotypic characteristics over time, although they can retain similar morphological and behavioural characteristics (Palumbi, 1994; Knowlton, 2000; Cowman \& Bellwood, 2013). The species that diverged as a consequence of the uplift of the Isthmus of Panama are closely related morphologically and genetically and are called transisthmian sister species pairs/complex (TSSP/TSSC) (Lessios, 2008; Marek, 2015; Marko, 2002). According to the transisthmian sister species complex concept, several species on one side of the Isthmus can represent the putative sister group of the species on the other side (Marek, 2015).

Transisthmian clades including isopods, echinoids, crustaceans, fishes and molluscs have already been identified on each side of the Isthmus of Panama based on molecular and fossil calibrated phylogenies (Graham, 1971; Lessios \& Weinberg, 1994; Lessios, 2008; Marko, 2015; O'Dea et al., 2016). Nesis (2003) stated that there are no cephalopod species occurring in both side of the IP, although nine pairs of similar species are known in the Eastern Pacific and Western Atlantic: two pairs of shallow-water squids (Family: Loliginidae) and seven pairs of benthic octopuses (Family: Octopodidae). According to Voight (1988), the high degree of similarity among pairs of pygmy, ocellated, common and striped octopod species, distributed along either side of Central America, is evidence that each pair shares a common ancestor, which is a more parsimonious explanation than convergent evolution.

The Superfamily Octopodoidea includes the families Octopodidae, Bathypolypodidae, Enteroctopodidae and Megaledonidae, which encompass a high diversity of benthic octopus. (Boyle \& Rodhouse, 2005, Norman, Hochberg \& Finn, 2014, Sanchez et al., 2018). Some species have a planktonic phase before settling on the substrate and are characterised by high fecundity (20,000-500,000 eggs) and small eggs (20-50 mm). Other species have low fecundity (50-800 eggs), large eggs (6-18 mm) and hatchlings that settle directly on the seabed (Mangold, 1987; Iglesias et al., 2007). The oceanographic characteristics such as temperature, ocean currents and productivity are important determinants of trait evolution of larvae and their dispersal ability (Robertson \& Collin, 2015). For this reason, the contrasting life history traits among octopod species make them an interesting model to study the processes of speciation and adaptive divergence after environmental changes caused by a vicariant event.

The consequences of forming the Isthmus of Panama were dramatic to marine biodiversity, ocean circulation and global climate. Thus, this study aims to understand how the uplift of the IP 
119 and the environmental changes caused by this vicariant event influenced speciation and dispersal

120 processes of octopod species in the Atlantic and Pacific oceans. Based on that, Bayesian time-

121 calibrated (biogeographical and fossil) phylogenetic analysis was performed to identify putative

122 transisthmian sister species pairs/complexes and verify whether the divergence time among the

123 octopod lineages coincides with the Pliocene or Miocene hypotheses.

\section{Material \& Methods}

\section{Data collection}

Tissue samples of octopod species were collected by snorkelling and SCUBA diving in Brazil (North-eastern coast and four oceanic islands) (permit SISBIO 10706-5 and 30484-1), from fish markets and landings in Mexico (Isla Mujeres, Sisal and port of Progreso) (Figure 1) (Table S1). Muscle tissue samples were taken from octopod arms preserved in 95\% ethanol and stored at $-20^{\circ} \mathrm{C}$.

Initial analyses were performed using sequences generated in the present study, and additional sequences were obtained from GenBank in order to evaluate the closest phylogenetic relationships among putative octopods sister species occurring in the Atlantic and Pacific. A total of 135 sequences from 30 cephalopods species (70 from this study and 65 obtained from GenBank) were chosen to estimate divergence times and infer phylogenetic relationships. The sequences of genes fragments generated in this study are accessible from GenBank under accession numbers (COI: MN933632- MN933651; 16S: MN508063- MN508082; rhodopsin: MN946381- MN946396; EF-1 $\alpha$ : MN946371- MN946380) (Table S1).

\section{Calibration priors}

Four fossils and also biogeographical information (Table 1) were used in order to calibrate the species tree. Calibration priors used include:

1-The biogeographic prior was the separation of deep sea Muusoctopus longibrachus subspecies (Muusoctopus longibrachus longibrachus Ibáñez, Sepúlveda and Chong, 2006 and Muusoctopus longibrachus akambei Gleadall, Guerro-Kommritz, Hochberg and Laptikhovsky, 2010) as a result of events related to the Last Glacial Maximum (LGM) proposed by Gleadall (2013). A normal prior was set on the $M$. longibrachus node with a mean of $24 \pm 5$ kya, yielding a range between 5\% and 95\% quartiles of 15-33 kya (Gleadall, 2013).

2-Divergence between Argonauta and Tremoctopus. An exponential prior was used based on the earliest record of the Argonautidae, the fossil Obinautilus pulcher from the Oligocene (29 Ma) (Kobayashi, 1954). The upper bound of $64 \mathrm{Ma}$ was placed at the last occurrence of ammonites as a prior 95\% confidence interval (CI) of the distribution of Argonauta. In the

153 Cretaceous, ammonite shells were abundant but were not recorded in the Tertiary. According to

154 Strugnell et al. (2008), although ammonites and argonauts have similar shells, there are no

155 Argonauta fossil records as old as ammonite records. Therefore, it is conservative to set this

156 upper bound on the prior $95 \% \mathrm{CI}$ of the distribution of argonauts at the last occurrence of

157 ammonites, 36 million years prior to their appearance in the fossil record. 
158

159

160

161

162

163

164

165

166

167

168

169

170

171

172

173

174

175

176

177

178

179

180

181

182

183

184

185

186

187

188

189

190

191

192

193

194

195

196

197

3- Split between the suborders Cirrata (Opisthoteuthis massyae) and Incirrata based on the fossils of Keuppia levante, K. hyperbolaris and Styletoctopus annae from the Upper Cenomanian, between the Toarcian (180 Ma) and the early Turonian (95 Ma). These fossils are regarded as the earliest representatives of the Incirrata (Fuchs, Bracchi \& Weis, 2009). This is represented by an exponential prior on the MRCA of these groups, with the minimum age of 95 $\mathrm{Ma}$ and $180 \mathrm{Ma}$ as an upper bound on the prior $95 \%$ confidence interval.

4-Separation of Vampyromorpha (Vampyroteuthis infernalis) and Octopoda. An exponential prior with lower bound of $162 \mathrm{Ma}$ was chosen based on the fossil Vampyronassa rhodanica from the Lower Callovian of the Jurassic (Fisher \& Riou, 2002). The upper bound of $250 \mathrm{Ma}$ was based on studies of Strugnell et al. (2006) and Kröger, Vinther, \& Fuchs (2011), who affirm that Vampyropods diverged by or before the Permian.

\section{Phylogenetic analysis}

Genomic DNA was extracted using the GF-1 Nucleic Acid Extraction kit (Vivantis, Malaysia) according to the manufacturer's instructions. Fragments of two mitochondrial (Cytochrome oxidase subunit I, COI and 16S rDNA) and two nuclear (Rhodopsin and Elongation Factor-1 $\alpha$, EF-1 $\alpha$ ) genes were amplified in this study. Cytochrome oxidase I gene amplicons were obtained using universal primers LCO1490 and HCO2198 (Folmer et al., 1994), and partial sequences of $16 \mathrm{~S}$ rDNA were amplified with the primers $16 \mathrm{SarL}$ and $16 \mathrm{SbrH}$ (Palumbi, 1996). The forward and reverse primers for amplification of Rhodopsin (RhFwd1 5' GATCGTTACAATGTCATCGGTAGACC 3', RhRev4 5' GAGAAAGAATGCGAAGATGCTA 3') and EF-1 $\alpha$ (EFFwd1 5' TCTGGTTGGCATGGTGATAACATG 3', EFRev3 5' ATTGTCATTAACCACCCTGGAC 3') were designed from octopus sequences available on GenBank using the software Geneious 9.0.2 (Kearse et al., 2012).

The PCR amplification reactions of all sequences were conducted in a final volume of 25 $\mu \mathrm{L}$ containing $1 \mu \mathrm{L}$ forward primer, $1 \mu \mathrm{L}$ reverse primer $(10 \mathrm{mM}), 12.5 \mu \mathrm{L}$ Taq DNA Polymerase Master Mix (Ampliqon A/S) or MyTaq RedMix (Bioline), $8.5 \mu \mathrm{L} \mathrm{H}_{2} \mathrm{O}$ and $2 \mu \mathrm{L}$ DNA (20-40 ng/ $\mu \mathrm{l})$. PCR cycle parameters used to amplify COI and $16 \mathrm{~S}$ genes were $3 \mathrm{~min}$ at $95^{\circ} \mathrm{C}$ for denaturation, followed by 35 cycles of $1 \mathrm{~min}$ at $94^{\circ} \mathrm{C}, 1 \mathrm{~min}$ at $45^{\circ} \mathrm{C}$ for annealing, 1.5 $\min$ at $72^{\circ} \mathrm{C}$ for extension and a final extension step of 4 min at $72^{\circ} \mathrm{C}$. The parameters used to amplify Rhodopsin and EF-1 $\alpha$ genes are detailed in Allcock, Strugnell, \& Johnson (2008). The PCR products were purified and sequenced by Macrogen Inc, Seoul, Korea.

Electropherograms were edited with Geneious 9.0.2 (Kearse et al., 2012), and sequences were aligned by ClustalW using Mega 6 (Tamura et al., 2013). Unalignable loop regions of 16S rDNA and gaps of EF1-alpha were removed before analysis using Gblocks software

(Castresana, 2000). The substitution model for each gene was chosen on the basis of the hierarchical and Akaike information criterion tests using the software jModeltest (Posada, 2008). The substitution models most suitable for each gene according to both tests were GTR $+\mathrm{G}(\mathrm{COI})$, GTR $+\mathrm{G}+\mathrm{I}(16 \mathrm{~S})$, and HKY85+G (rhodopsin and EF1-alpha). 
198

199

200

201

202

203

204

205

206

207

208

209

210

211

212

213

214

215

216

217

218

219

220

221

222

223

224

225

226

227

228

229

230

231

232

233

234

235

236

237

Bayesian phylogenetic inference on the subset of sequences was carried out in BEAST 1.8.4 (Drummond et al., 2012). A total of 33 specimens (COI-33, 16S rDNA-32, rhodopsin27, EF1-alpha-8) were included in subsequent analyses as separate partitions with unlinked substitution models and linked clock and tree models. An uncorrelated lognormal relaxed clock model incorporating Yule speciation-process prior on branching rates was used. Monte Carlo Markov Chain (MCMC) runs were performed for $3 \times 10^{8}$ generations, sampling one tree each $3 \times 10^{4}$ runs. The convergence of MCMC runs, effective sample size and the correct 'burn-in' for the analysis were assessed using Tracer v1.6 (Rambaut et al., 2014). A consensus tree accessing the posteriori probability values of each clade was generated using TreeAnnotator 1.8.3 (Drummond et al., 2012) and displayed using FigTree 1.4.3.

\section{Biogeographical analysis}

The distribution ranges of the species were divided into four areas: Western Atlantic (WA), Eastern Atlantic (EA), Western Pacific (WP) and Eastern Pacific (EP) (Figure 1).

Reconstruct Ancestral State in Phylogenies (RASP) software package (Yu, Harris, Blair, \& $\mathrm{He}, 2015$ ) was used to infer historical biogeography of the lineages, based on present-day distributions of cephalopods species (Norman et al., 2014). We used the Bayesian Binary Method (BBM) to estimate the probabilities of ancestral ranges by calculating the average probability of presence (1) and absence (0) over all sampled generations of the ancestral species in each area (Yu et al., 2015). Events of vicariance, dispersal and extinction, as well as the route of dispersal on the nodes, were also calculated by BBM model in RASP. The analysis was carried out with the Maximum Clade Credibility Tree (MCCT) from BEAST phylogenetic reconstruction, setting four heated $\mathrm{MCMC}$ chains, which run simultaneously for $5 \times 10^{6}$ generations, sampled every 1,000 generations.

The Time-Event Curve (TEC) was obtained by re-calculating the time of each node using the time of the root. The events on the node were treated using a modified Gaussian distribution (Yu et al., 2015). Thus, events of extinction, dispersal and vicariance are assigned to a time frame. This analysis was also carried out using RASP.

All the clades considered as transisthmian must contain species from each side of the IP and must have diverged after a vicariance event indicated by the RASP analysis.

\section{Results}

A total of 1,992 bp of the combined dataset (COI-609, 16S - 396, rhodopsin - 546, EF-441) were used to infer phylogenetic relationships and divergence times among 30 cephalopod species.

\section{Phylogenetic analysis}

The Bayesian phylogenetic tree, built using a relaxed phylogenetic approach, reveals three well-supported clades of transisthmian octopus species pair/complex (clades 1, 3, 5) that underwent vicariance processes as indicated by the RASP analysis (Figure 2). Two other clades 
238

239

240

241

242

243

244

245

246

247

248

249

250

251

252

253

254

255

256

257

258

259

260

261

262

263

264

265

266

267

268

269

270

271

272

273

274

275

were also recovered, in which the divergence processes among the species showed a low probability of having been influenced by the IP (clades 2 and 4) (Figure 2). The divergence time estimation indicated that the mean age of separation among TSSP/TSSC varied from 5.22 to 17.24 Ma (Table 2).

Clade 1 is composed by the deep sea Muusoctopus species (Family: Enteroctopodidae) and is characterised by two vicariant events. The first occurred 11.39 million years ago (5.08, 20.77 95\% HPD) at the divergence of $M$. januari (WA) and a clade containing M. yaquinae (EP) and M. longibrachus subspecies (Posterior probability $[\mathrm{PP}]=1$ ). The second vicariance event corresponds to the divergence of $M$. longibrachus longibrachus and M. longibrachus akambei.

Clade 2 comprises the nocturnal species Callistoctopus ornatus from WP and Callistoctopus sp. and C. macropus from WA and EA, respectively $(\mathrm{PP}=1)$. The divergence between those two lineages from Atlantic and Pacific was estimated to occur 5.22 Ma (2.21, 10.96 95\% HPD).

The pygmy octopuses (Paroctopus) species that are distributed in both sides of the Isthmus of Panama formed a highly-supported monophyletic clade (clade 3, PP =1). These Paroctopus species diverged from the most recent common at 17.44 Ma (8.99, 30.31 95\% HPD).

The long-armed mimic octopuses Macrotritopus defilippi from the Western Atlantic and Octopodidade sp. (White V, as referred by Norman 2000) from the Western Pacific are sister taxa $(\mathrm{PP}=1)$ and are estimated to have diverged $7.83 \mathrm{Ma}(2.82,15.8895 \%$ HPD), as shown in clade 4.

The transisthmian sister species complex in clade 5 form a well-supported monophyletic group $(\mathrm{PP}=1)$ and were estimated to have had a common ancestor $8.03 \mathrm{Ma}(4.27,13.5895 \%$ HPD) $(\mathrm{PP}=1)$. In this clade, $O$. insularis, $O$. maya and $O$. hummelincki from WA are the sister taxa to $O$. mimus and $O$. hubbsorum from EP and seem to have diverged after a vicariance event, indicated by the RASP analysis.

\section{Biogeographical analysis}

Reconstruct Ancestral State in Phylogenies (RASP) showed that the most recent common ancestors of the TSSP/TSSC originated in the Pacific Ocean (Table 2). Clades 1, 3 and 5 had high probabilities of an ancestral distribution in the East Pacific ( $\mathrm{PP}=0.88,0.87,0.87$, respectively). Clades 2 and 4 were estimated to have originated from ancestors distributed in the Western Pacific Ocean ( $\mathrm{PP}=0.37$ and 0.88 , respectively). The dispersal routes for each TSSP/TSSC clade estimated by Bayesian Binary Method are shown in the Table 2.

The biogeographical analysis revealed five vicariant and ten dispersal events on the wellsupported nodes of five transisthmian species pair/complex during the early Miocene to early Pliocene (Table 2). The time-event curve (TEC) analysis shows an increase of vicariant and dispersal events after the middle Miocene ( 15 Ma), with a peak in the Early Pliocene ( $\sim \mathrm{Ma})$. 


\section{Discussion}

277 Bayesian phylogenetic inference revealed transisthmian sister species pair/complexes in

278 three genera of octopod species and low probabilities in two genera. These species diverged

279 between 18 and $5 \mathrm{Ma}$, before the closure of the Isthmus of Panama suggested by the Late

280 Pliocene model (3 Ma). The ancestral area reconstruction analysis showed vicariant events on

281

282 each node of TSSP/TSSC and an increase of dispersal and vicariance during the process of

283 isthmus formation, which indicates an influence of the emergence of the geological barrier

284 (Isthmus of Panama) on the divergence processes among octopod species. In addition, the RASP results suggest that the most recent common ancestor of the five clades occupied the Pacific Ocean, and the most probable route of dispersal before the closure of the IP is from Pacific to Atlantic.

The divergence times estimated in the present study revealed that octopods TSSP/TSSC

289 from Atlantic and Pacific diverged between the Middle Miocene and Early Pliocene (mean range =5-18 Ma). This suggests that after $15 \mathrm{Ma}$ (age of the isthmus final closure in the Miocene model), there was likely sufficient connectivity between Caribbean and Pacific oceans to maintain dispersal for some octopus species between these locations up until as recently as the Early Pliocene.

293

294

The emergence of the Isthmus of Panama was a long process that caused profound but gradual changes in a range of oceanographic conditions, including temperature, salinity, circulation and productivity (O'Dea et al., 2016). The seaway is understood to have been shallowing by the Middle Miocene, decreasing in depth from over 2,000 m to less than 1,000 m deep (Coates, 1997). Reorganisations of ocean circulation from eastward-flowing to westwardflowing occurred during the Late Oligocene increased productivity within the Caribbean during the Early Miocene (Bartoli et al., 2005; Schneider \& Schmittner, 2006). Temperature and salinity began to increase approximately $7 \mathrm{Ma}$ (Collins, 1996). Around $4 \mathrm{Ma}$, the narrowing of the seaway began to extinguish Caribbean upwelling and the primary productivity of this region dropped dramatically, while it increased in the Eastern Pacific (Pennington et al., 2006; Lessios, 2008; Coates \& Stallard, 2013; Leigh et al., 2013).

304 Considering that the oceanographic changes were so strong as to affect the global climate (Lear, Rosenthal \& Wright, 2003), we suggest that octopods TSSP/TSSC probably diverged as a consequence of these physical and environmental barriers, even before the complete uplift of the IP 3 Ma suggested by the Late Pliocene model. A revision carried out by Lessios (2008) indicated that 73 from 115 geminate clades, including echinoids, crustaceans, fishes and molluscs, split earlier to the final closure of the IP. A similar result was verified by O'Dea et al. (2016), who used 38 comparisons based on fossil-calibrated phylogenies and revealed that 26

311 (68\%) produced estimates of separation that occurred more recently than 12 Ma. Marko et al.

312 (2002), studying divergences among six pairs of geminates in the Arcidae bivalves, also reported

313 that isolation of geminate species did not necessarily occur in the latest stages of closure of the

314 Central American Seaway. 
315 The soft-bodied cephalopods are poorly represented in the fossil record, which makes 316 estimating divergence times of octopuses challenging (Strugnell et al., 2006). However, 317 divergence times of non-calibrated nodes generated in the present study are consistent with 318 previous studies. Using two biogeographical calibrations (LGM and uplift of the IP), Gleadall 319 (2013) estimated that Enteroctopus and Muusoctopus lineages separated $22+/-2.2 \mathrm{Ma}$, which is 320 in accordance with this study (22 Ma, 10-40 95\% HPD in this study). The age of separation between the M. januari and M. yaquinae clades (11 Ma, 5-21 95\% HPD) is also in accordance with Gleadall's (2013) results (13.4 Ma). Furthermore, Amor et al. (2014), using the rate of evolution for COI in cephalopods, estimated 19.0-40.9 Ma for the segregation between the $O$. vulgaris and O. mimus groups, which is in accordance with the results of this study (29 Ma, 1843 95\% HPD).

According to the reconstruction ancestral area analysis, the most recent common ancestors 326

327

328

329

330

331

332

333

334

335

336

337

338

339

340

341

342

343

344

345

346

347

348

349

350

351

352

353

354 of all octopod TSSP/TSSC originated from the Pacific Ocean. The shift in the ocean circulation flow from east-west to west-east would carry paralarvae of many species from the Pacific to the Atlantic before the final closure of the IP (Bartoli et al., 2005; Schneider \& Schmittner, 2006). Several studies have proposed that many Caribbean species of bivalve, gastropod and fish also derived from Pacific ancestors (Bermingham, McCafferty, \& Martin, 1997; Meyer, 2003; Leigh et al., 2013; LaBella et al., 2017). Additionally, Leigh et al. (2013) pointed out that fossil evidence indicates a Pacific origin for six gastropod species that occupied both sides of tropical America and have become extinct in the Atlantic.

The earliest divergence of all octopods TSSP/TSSC investigated in this study occurred between the pygmy octopuses $P$. digueti from Eastern Pacific and $P$. mercatoris/P. cf. joubini from the Western Atlantic $17.44 \mathrm{Ma}(8.99,30.3195 \% \mathrm{HPD}$, clade 3$)$. Lower fecundity rates (20-320 eggs and benthic hatchling) (Forsythe \& Toll, 1991) combined with small adult size (body weight from $20 \mathrm{~g}$ to $85 \mathrm{~g}$ ) (Norman et al., 2014) may have reduced the ability of these species to maintain dispersal after the first environmental changes resulting from the formation of the IP.

The divergence among the deep-sea species M. januari and M. yaquinae group was around $11 \mathrm{Ma}(5.08,20.7795 \% \mathrm{HPD}$, clade 1). This split was probably influenced by the shoaling of the IP, which shut off deep water connection between 12 and $9.2 \mathrm{Ma}$ (Coates et al., 1992; Lear et al., 2003). The deep divergences among transisthmian species can also be explained by the extinction of geminates as a consequence of the uplift of the isthmus (Leigh et al., 2013; Lessios, 1998). Marko (2002) affirms that molluscan transisthmian taxa from the EP and the WA may be rare due to successive events of extinction caused by the seaway closure, in which at least $70 \%$ of some molluscan subgeneric groups were lost.

The clade that included Macrotritopus defilippi from the Western Atlantic and Octopodidae sp. (White V) (Norman, 2000) from the Western Pacific shared a MRCA up to 8 Ma $(2.82,15.88$ 95\% HPD, clade 4). These sand-dwelling species have similar morphological and complex behavioural characteristics, such as mimicry and 'flatfish swimming' (octopus that mimicked the shape, swimming actions, speed, duration and the colouration of swimming 
355 flounders) (Hanlon, Conroy \& Forsythe, 2008). They also appear to have evolved from a sand356 dwelling common ancestor with extremely long arms (Huffard et al., 2010) and with small and 357 planktonic eggs at the Pacific Ocean. However, these relationships and routes of dispersal may 358 be biased because the M. defilippi from the Mediterranean Sea (locality of the species holotype)

359

360

361

362

363

364

365

366

367

368

369

370

371

372

373

374

375

376

377

378

379

380

381

382

383

384

385

386

387

388

389

390

391

392

393

394 was not available for this analysis.

The most recent divergence in our analysis is the nocturnal Callistoctopus species from the Western Pacific and Western Atlantic at 5 Ma (2.21, 10.96 95\% HPD, clade 2). Callistoctopus ornatus occupies a broad area of the Indian and Western and Central Pacific Oceans, while $C$. macropus occurs in the Mediterranean Sea and Eastern Atlantic Ocean (Norman et al., 2014; Voss, 1981). The nocturnal Callistoctopus sp. from the Brazilian coast is morphologically, genetically and behaviourally similar to C. ornatus and C. macropus (TS Leite and FD Lima personal communication). Additionally, all the species in clade 2 have small and planktonic hatchlings, which may have facilitated their dispersal and diversification across the seas (Boyle \& Rodhouse, 2005; Norman et al., 2014). The BBM analysis pointed to the WP-WA as more plausible dispersal route of the nocturnal species, suggesting that the channel before the final closure of the IP was the likely pathway. However, the posterior probability is low (PP BBM route $=0.37$ ), which suggests that alternative routes of colonisation, such as from Indo-Pacific to Eastern Atlantic, were also likely to have been taken. Schneider and Schmittner (2006) pointed out a connection between the tropical gateways of Panama and Indonesia in the way that reduced outflow of upper Pacific Ocean waters via the Panama seaway into the Atlantic is compensated by increased flow towards the Indonesian Archipelago. Given that the divergence of these species occurred shortly before the total closure of the isthmus, this interflow may explain the dispersal of species from the West to East Pacific and, subsequently to the West Atlantic via the Panama Seaway.

Clade 5 includes Octopus species with remarkable evolutionary success in term of diversification, distribution and abundance on both sides of the Americas. This TSSC groups includes $O$. maya, O. hummelincki and $O$. insularis from the WA and $O$. mimus and $O$.

hubbsorum from the EP, which have different reproductive strategies and shared a common ancestor $8 \mathrm{Ma}(4.27,13.58$ 95\% HPD). The species $O$. mimus and $O$. hubbsorum are closely related and may represent a single species (Pliego-Cárdenas et al., 2014). They are the putative transisthmian sister taxa of $O$. insularis, because they also share similar morphological characteristics (medium/large muscular species, ocellus absent, white spots on dorsal mantle, skin texture of irregular patches and a groove system), habitat preferences (reefs and rocky bottoms in shallow waters) and life history (small and planktonic eggs) (Leite et al., 2008; Leite et al. 2009; Norman et al., 2014).

Prior to the divergence of the species in clade 5 , speciation processes appear to have occurred within the Eastern Pacific around $19 \mathrm{Ma}$ (10-29 95\% HPD). These processes led to a clade containing two ocellated species with different reproductive traits $(O$. bimaculoides and $O$. bimaculatus, holobenthic and pelagobenthic hatchlings, respectively) in EP and another clade containing the endemic ocellated species from the Galapagos, O. oculifer (holobenthic mode), 
395

396

397

398

399

400

401

402

403

404

405

406

407

408

409

410

411

412

413

414

415

416

417

418

419

420

421

422

423

424

425

426

427

428

429

430

431

432

433

434

and the species of clade 5 . The divergence between $O$. oculifer and clade 5 (12 Ma, 7-20 95\% HPD) occurred slightly after the formation of seamounts in Galápagos at $14.5 \mathrm{Ma}$ (Werner et al., 1999), suggesting that this species successfully settled around the rising island and became endemic due to its low dispersive ability.

Even though the divergence of $O$. oculifer was not precipitated by a vicariance event related to the formation of IP, the subsequent evolutionary processes were and seem to have generated a species with very similar characteristics in WA, O. maya. They share important biological features, such as large eggs and benthic hatchlings (Arreguin-Sánchez, Solis-Ramirez, $\&$ Rosa, 2000), which means they probably inherited these traits from a common ancestor. Although some studies have pointed $O$. bimaculatus as the transisthmian sister taxon of $O$. maya (Voight, 1988; Juárez, Rosas \& Arenta-Ortiz, 2012; Nesis, 2003; Allcock, Lindgren \& Strugnell, 2015), this study suggests that $O$. oculifer is the sister transisthmian species of $O$. maya, since they also share morphological, behavioural and ecological similarities.

\section{Conclusions}

The long geological history of the Isthmus of Panama had an immense impact on the speciation processes of marine biota in the Atlantic and Pacific Oceans (Coates et al., 1992; Bartoli et al., 2005; O'Dea et al., 2007; Coates \& Stallard, 2013; O'Dea et al., 2016). The divergence processes among octopods TSSP/TSSC probably occurred up to $5 \mathrm{Ma}(2.21 \mathrm{Ma}$, lower bound of the 95\% HPD interval), a long time after the final closure of the IP proposed by the Miocene model, $15 \mathrm{Ma}$. Considering the influence of the extreme environmental changes during this geological event in the speciation processes, this study indicates that the divergence times of the octopod species are according to the classic Pliocene model.

The results obtained in this phylogenetic reconstruction suggest that it is more probable that the differences among the lineages of octopod transisthmian species arose due to the allopatric speciation process caused by the uplift of Isthmus of Panama than that they arose due to an independent process of evolutionary convergence.

\section{Acknowledgements}

We are thankful to the Chico Mendes Institute for Biodiversity Conservation (MMA/ICMBIO) and the Brazilian Navy for logistics support in the field work. We are also grateful to Carlos Rosas, Jaciana Barbosa, Diego Batista and Leocledna Oliveira for helping in the data collection.

\section{References}

Allcock AL, Strugnell J, Johnson MP. 2008. How useful are the recommended counts and indices in the systematics of the Octopodidae (Mollusca: Cephalopoda). Biological Journal of the Linnean Society 95:205-218. DOI: 10.1111/j.1095-8312.2008.01031.x

Allcock AL, Lindgren A, Strugnell JM. 2015. The contribution of molecular data to our understanding of cephalopod evolution and systematics: a review. Journal of Natural History 49:1-49. DOI: 10.1080/00222933.2013.825342

Peer) reviewing PDF | (2019:06:38484:2:0:NEW 20 Jan 2020) 
435

436

437

438

439

440

441

442

443

444

445

446

447

448

449

450

451

452

453

454

455

456

457

458

459

460

461

462

463

464

465

466

467

468

469

470

471

472

473

474

Amor MD, Norman MD, Cameron HE, Strugnell JM. 2014. Allopatric speciation within a cryptic species complex of Australasian octopuses. PLoS ONE 9:1-6. DOI: 10.1371/journal.pone.0098982

Arreguín-Sánchez F, Solís MJ, González De La Rosa ME. 2000. Population dynamics and stock assessment for Octopus maya (Cephalopoda: Octopodidae) fishery in the Campeche Bank, Gulf of Mexico. Revista de Biologia Tropical 48:323-331.

Bacon CD, Mora A, Wagner WL, Jaramillo CA. 2013. Testing geological models of evolution of the Isthmus of Panama in a phylogenetic framework. Botanical Journal of the Linnean Society 171:287-300. DOI: 10.1111/j.1095-8339.2012.01281.x

Bacon CD, Silvestro D, Jaramillo C, Smith BT, Chakrabarty P, Antonelli A. 2015. Biological evidence supports an early and complex emergence of the Isthmus of Panama. Proceedings of the National Academy of Sciences 112:6,110-6,115. DOI: 10.1073/pnas.1423853112

Bartoli G, Sarnthein M, Weinelt M, Erlenkeuser H, Lea DW. 2005. Final closure of Panama and the onset of northern hemisphere glaciation. Earth and Planetary Science Letters 237:3344. DOI: $10.1016 /$ j.epsl.2005.06.020

Bermingham E, Lessios HA. 1993. Rate variation of protein and mitochondrial DNA evolution as revealed by sea urchins separated by the Isthmus of Panama. Proceedings of the National Academy of Sciences 90:2,734-2,738. DOI: 10.1073/pnas.90.7.2734

Bermingham E, Shawn McCafferty S, Martin AP. 1997. Fish Biogeography and Molecular Clocks: Perspectives from the Panamanian Isthmus. In: Kocher TD, Stepien CA eds. Molecular Systematics of Fishes. New York: Academic Press, 113-128. DOI: 10.1016/B978-012417540-2/50009-9

Boyle P, Rodhouse PG. 2005. Cephalopods: ecology and fisheries. Oxford: Blackwell Science.

Castresana J. 2000. Selection of conserved blocks from multiple alignments for their use in phylogenetic analysis. Molecular Biology and Evolution 17:540-552. DOI: 10.1093/oxfordjournals.molbev.a026334

Coates AG, Jackson JBC, Collins LS, Cronin TM, Dowsett HJ, Bybell LM, Jung P, Obando JA. 1992. Closure of the Isthmus of Panama: the near-shore marine record of Costa Rica and Western Panama. Geological Society of America Bulletin 104:814-828. DOI: https://doi.org/10.1130/0016-7606(1992)104<0814:COTIOP >2.3.CO;2

Coates AG. 1997. The Forging of Central America. In: Coates AG ed. Central America: A Natural and Cultural History. New Haven: Yale University Press, 1-37.

Coates AG, Collins LS, Aubry MP, Berggren WA. 2004. The geology of the Darien, Panama, and the late Miocene-Pliocene collision of the Panama arc with Northwestern South America. Geological Society of America Bulletin 116:1,327-1,344. DOI: 10.1130/B25275.1

Coates AG, Stallard RF. 2013. How old is the isthmus of Panama? Bulletin of Marine Science 89:801-813. DOI: $10.5343 / \mathrm{bms} .2012 .1076$

Collins T. 1996. Molecular Comparisons of Transisthmian Species Pairs: Rates and Patterns of Evolution. In: Jackson JBC, Budd AF, Coates AG eds. Evolution and Environment in Tropical America. Chicago: University of Chicago Press, 303-334.

Peer] reviewing PDF | (2019:06:38484:2:0:NEW 20 Jan 2020) 
475

476

477

478

479

480

481

482

483

484

485

486

487

488

489

490

491

492

493

494

495

496

497

498

499

500

501

502

503

504

505

506

507

508

509

510

511

512

513

514

515

Cowman PF, Bellwood DR. 2013. Vicariance across major marine biogeographic barriers: temporal concordance and the relative intensity of hard versus soft barriers. Proceedings of the Royal Society B: Biological Sciences 280. DOI: 10.1098/rspb.2013.1541

Drummond AJ, Suchard MA, Xie D, Rambaut A. 2012. Bayesian phylogenetics with BEAUti and the BEAST 1.7. Molecular Biology and Evolution 29:1,969-1,973. DOI: $10.1093 / \mathrm{molbev} / \mathrm{mss} 075$

Fisher JC, Riou B. 2002. Vampyronassa rhodanica nov. gen. nov. sp., vampyromorpha (Cephalopoda, Coleoidea) du Callovien inférieur de la Voulte-sur-Rhône (Ardéche, France). Annales de Paléontologie 88:1-17. DOI: 10.1016/S0753-3969(02)01037-6

Folmer O, Black M, Hoeh W, Lutz R, Vrijenhoek R. 1994. DNA primers for amplification of mitochondrial cytochrome c oxidase subunit I from diverse metazoan invertebrates. Molecular marine biology and biotechnology 3:294-299.

Forsythe JW, Toll RB. 1991. Clarification of the Western Atlantic Ocean pygmy octopus complex: the identity and life history of Octopus joubini (Cephalopoda: Octopodinae). Bulletin of Marine Science 49:88-97.

Fuchs D, Bracchi G, Weis R. 2009. New Octopods (Cephalopoda: Coleoidea) from the Late Cretaceous (Upper Cenomanian) of Hâkel Hândjoula, Lebanon. Palaeontology 52:65-81. DOI: $10.1111 /$ j.1475-4983.2008.00828.x

Galván-Quesada S, Doadrio I, Alda F, Perdices A, Reina RG, Varela MG, Hernández N, Mendoza AC, Bermingham E, Domínguez-Domínguez O. 2016. Molecular phylogeny and biogeography of the amphidromous fish genus dormitator gill 1861 (Teleostei: Eleotridae). PLoS ONE 11:1-26. DOI: 10.1371/journal.pone.0153538

Gleadall IG. 2013. A molecular sequence proxy for Muusoctopus januarii and calibration of recent divergence among a group of mesobenthic octopuses. Journal of Experimental Marine Biology and Ecology 447:106-122. DOI: 10.1016/j.jembe.2013.02.017

Graham JB. 1971. Temperature tolerances of some closely related tropical Atlantic and Pacific fish species. Science 172:861-863. DOI: 10.1126/science.172.3985.861

Hanlon RT, Conroy LA, Forsythe JW. 2008. Mimicry and foraging behaviour of two tropical sand-flat octopus species off North Sulawesi, Indonesia. Biological Journal of the Linnean Society 93:23-38. DOI: 10.1111/j.1095-8312.2007.00948.x

Haug GH, Tiedemann R. 1998. Effect of the formation of the Isthmus of Panama on Atlantic Ocean thermohaline circulation. Letters to Nature 393:673-676. DOI: http://dx.doi.org/10.1038/31447

Hoorn C, Flantua S. 2015. An early start for the Panama land bridge. Science 348:186-187. DOI: 10.1126/science.aab0099

Huffard CL, Saarman N, Hamilton H, Simison WB. 2010. The evolution of conspicuous facultative mimicry in octopuses: an example of secondary adaptation? Biological Journal of the Linnean Society 101:68-77. DOI: 10.1111/j.1095-8312.2010.01484.x

Iglesias J, Sanchez F, Bersano J, Carrasco J, Dhont J, Fuentes L, Linares F, Munoz J, Okumura S, Roo J. 2007. Rearing of Octopus vulgaris paralarvae: present status, bottlenecks and trends. Aquaculture 266:1-15. DOI: 10.1016/j.aquaculture.2007.02.019

Peer) reviewing PDF | (2019:06:38484:2:0:NEW 20 Jan 2020) 
516 Juárez O, Rosas C, Arenta-Ortiz M. 2012. Phylogenetic relationships of Octopus maya revealed by mtDNA sequences. Ciencias Marinas 38:563-575. DOI: $10.7773 / \mathrm{cm} . v 38 i 3.1962$

518 Kearse M, Moir R, Wilson A, Stones-Havas S, Cheung M, Sturrock S, Buxton S, Cooper A,

519 Markowitz S, Duran C, Thierer T, Ashton B, Meintjes P, Drummond A. 2012. Geneious

520

521

522 Basic: an integrated and extendable desktop software platform for the organization and analysis of sequence data. Bioinformatics 28:1,647-1,649 DOI:

10.1093/bioinformatics/bts 199

523

524

Keigwin L. 1982. Isotopic paleoceanography of the Caribbean. Science 217:350-353. DOI: $10.1126 /$ science. 217.4557 .350

525

526

527

Knowlton N, Weigt LA, Solórzano LA, Mills DK, Bermingham E. 1993. Divergence in protein, mitochondrial DNA, and reproductive compatibility across the Isthmus of Panama. Science 260:1,629-1,632. DOI: 10.1126/science.8503007

528

529

530

531

532

Knowlton N, Weigt LA. 1998. New dates and new rates for divergence across the Isthmus of Panama. Proceedings of the Royal Society of London B 265:2,257-2,263. DOI: 10.1098/rspb.1998.0568

Knowlton N. 2000. Molecular genetic analyses of species boundaries in the sea. Hydrobiologia 420:73-90. DOI: https://doi.org/10.1023/A:1003933603879

533

Kobayashi T. 1954. A new Palaeogene paracenoceratoid from Southern Kyushu in Japan.

534 Japanese Journal of Geology and Geography 24:181-184.

535

536

537

538

539

540

541

542

543

544

545

546

Kröger B, Vinther J, Fuchs D. 2011. Cephalopod origin and evolution: a congruent picture emerging from fossils, development and molecules. Bioessays 33:602-613. DOI: 10.1002/bies.201100001

LaBella AL, Van Dover CL, Jollivet D, Cunningham CW. 2017. Gene flow between Atlantic and Pacific Ocean basins in three lineages of deep-sea clams (Bivalvia: Vesicomyidae: Pliocardiinae) and subsequent limited gene flow within the Atlantic. Deep-Sea Research II 137:307-317. DOI: 10.1016/j.dsr2.2016.08.013

Lear CH, Rosenthal Y, Wright JD. 2003. The closing of a seaway: Ocean water masses and global climate change. Earth and Planetary Science Letters 210:425-436. DOI: 10.1016/S0012-821X(03)00164-X

Leigh EG, O’Dea A, Vermeij GJ. 2013. Historical biogeography of the Isthmus of Panama. Biological Reviews 89:148-172. DOI: 10.1111/brv.12048

Leite TS, Haimovici M, Molina W, Warnke K. 2008. Morphological and genetic description of Octopus insularis, a new cryptic species in the Octopus vulgaris complex (Cephalopoda: Octopodidae) from the tropical Southwestern Atlantic. Journal of Molluscan Studies 74:6374. DOI: 10.1093/mollus/eym050

Leite TS, Haimovici M, Mather J, Oliveira JEL. 2009. Habitat, distribution, and abundance of the commercial octopus (Octopus insularis) in a tropical oceanic island, Brazil: information for management of an artisanal fishery inside a marine protected area. Fisheries Research

553

554

555 98:85-91. DOI: 10.1016/j.fishres.2009.04.001

Lessios HA. 1981. Divergence in allopatry: molecular and morphological differentiation between 556 sea urchins separated by the Isthmus of Panama. Evolution 35:618-634. DOI: 
557

558

559

560

561

562

563

564

565

566

567

568

569

570

571

572

573

574

575

576

577

578

579

580

581

582

583

584

585

586

587

588

589

590

591

592

593

594

595

596

https://doi.org/10.2307/2408235

Lessios HA, Weinberg JR. 1994. Genetic and morphological divergence among Morphotypes of the isopod excirolana on the two sides of the Isthmus of Panama. Society 48:530-548. https://doi.org/10.1111/j.1558-5646.1994.tb01342.x

Lessios H. 1998. The First Stage of Speciation as Seen in Organism Separated by the Isthmus of Panama. In: Howard, DJ, Berlocher SH, eds. Species and Speciation. Oxford University Press, 185-201.

Lessios HA. 2008. The great American schism: divergence of marine organisms after the rise of the Central American Isthmus. Annual Review of Ecology, Evolution, and Systematics 39:63-91. DOI: 10.1146/annurev.ecolsys.38.091206.095815

Mangold, K. 1987. Reproduction. In: Boyle, PR, ed. Cephalopod Life Cycles II-Comparative Reviews. London: Academic Press: 157-200.

Marek C. 2015. Dissertation The Emergence of the Isthmus of Panama-A Biological Perspective. Ph.D. Thesis, Universität Gießen, Germany.

Marko PB. 2002. Fossil calibration of molecular clocks and the divergence times of geminate species pairs separated by the Isthmus of Panama. Molecular Biology and Evology 19:2,005-2,021. DOI: 10.1093/oxfordjournals.molbev.a004024

Meyer CP. 2003. Molecular systematics of cowries (Gastropoda: Cypraeidae) and diversification patterns in the tropics. Biological Journal of the Linnean Society 79:401-459. DOI: 10.1046/j.1095-8312.2003.00197.x

Montes C, Cardona A, McFadden R, Morón SE, Silva CA, Restrepo-Moreno S, Ramírez DA, Hoyos N, Wilson J, Farris D, Bayona GA, Jaramillo CA, Valencia V, Bryan J, Flores JA. 2012. Evidence for middle Eocene and younger land emergence in Central Panama: implications for Isthmus closure. Geological Society of America Bulletin 124:780-799. DOI: $10.1130 / \mathrm{B} 30528.1$

Montes C, Cardona A, Jaramillo C, Pardo A, Silva JC, Valencia V, Ayala C, Pérez-Angel LC, Rodriguez-Parra LA, Ramirez V, Niño H. 2015. Middle Miocene closure of the Central American Seaway. Science 348:226-229. DOI: 10.1126/science.aaa2815

Nesis KN. 2003. Distribution of recent Cephalopoda and implications for Plio-Pleistocene events. Berliner Paläobiol. Abh 3:199-224.

Norman M. 2000. Cephalopods-A World Guide. Hackenheim: ConchBooks.

Norman MD, Hochberg FG, Finn JK. 2014. Octopus and vampire squids. In: Jereb P, Roper CFE, Norman MD, Finn JK, eds. Cephalopods of the World. An Annotated and Illustrated Catalogue of Cephalopod Species Known to Date. Rome: FAO, 33-58.

O’Dea A, Jackson JBC, Fortunato H, Smith JT, D’Croz L, Johnson KG, Todd JA. 2007. Environmental change preceded Caribbean extinction by 2 million years. Proceedings of the National Academy of Sciences of the United States of America 104:5,501-5,506. DOI: 10.1073/pnas.0610947104

O'Dea AO, Lessios HA, Coates AG, Eytan RI, Restrepo-moreno SA, Cione AL, Collins LS, Queiroz A De, Farris DW, Norris RD, Stallard RF, Woodburne MO, Aguilera O, Aubry M, 
597

598

599

600

601

602

603

604

605

606

607

608

609

610

611

612

613

614

615

616

617

618

619

620

621

622

623

624

625

626

627

628

629

630

631

632

633

634

635

636

637

Berggren WA, Budd AF, Cozzuol MA, Coppard SE, Duque-caro H, Finnegan S, Gasparini GM, Grossman EL, Johnson KG, Keigwin LD, Knowlton N, Leigh EG, Leonard-pingel JS, Marko PB, Pyenson ND, Rachello-dolmen PG, Soibelzon E, Soibelzon L, Todd JA, Vermeij GJ, Jackson JBC. 2016. Formation of the Isthmus of Panama. Science Advances 2:1-11. DOI: $10.1126 /$ sciadv.1600883

Parham JF, Donoghue PCJ, Bell CJ, Calway TD, Head JJ, Holroyd PA, Inoue JG, Irmis RB, Joyce WG, Ksepka DT, Patané JSL, Smith ND, Tarver JE, Van Tuinen M, Yang Z, Angielczyk KD, Greenwood JM, Hipsley CA, Jacobs L, Makovicky PJ, Müller J, Smith KT, Theodor JM, Warnock RCM, Benton MJ. 2012. Best practices for justifying fossil calibrations. Systematic Biology 61:346-359. DOI: 10.1093/sysbio/syr107

Palumbi SR. 1994. Genetic divergence, reproductive isolation, and marine speciation. Annual Review of Ecology and Systematics 25:547-572. DOI: 10.1146/annurev.es.25.110194.002555

Palumbi, S. R. 1996. Nucleic acids II: The Polymerase Chain Reaction. In: Hillis DM, Moritz C, Mable BK, eds. Molecular Systematics. Sunderland, MA: Sinauer Associates Inc, 205-247.

Pennington JT, Mahoney KL, Kuwahara VS, Kolber DD, Calienes R, Chavez FP. 2006. Primary production in the eastern tropical Pacific: a review. Progress in Oceanography 69:285-317. DOI: $10.1016 /$ j.pocean.2006.03.012

Pliego-Cárdenas R, Hochberg FG, León FJG De, Barriga-Sosa IDLA. 2014. Close genetic relationships between two American octopuses: Octopus hubbsorum Berry, 1953, and Octopus mimus Gould, 1852. Journal of Shellfish Research 33:293-303. DOI: 10.2983/035.033.0128

Rambaut A, Suchard MA, Xie D, Drummond AJ. 2014. Tracer v1.6. Available at http://tree.bio.ed.ac.uk/software/tracer (accessed 13 June 2017).

Robertson DR, Collin R. 2015. Inter- and Intra-specific variation in egg size among reef fishes across the Isthmus of Panama. Frontiers in Ecology and Evolution 2:1-15. DOI: $10.3389 /$ fevo.2014.00084

Sanchez G, Setiamarga DHE, Tuanapaya S, Tongtherm K, Winkelmann IE, Schmidbaur H, Umino T, Albertin C, Allcock L, Perales-Raya C, Gleadall I, Strugnell JM, Simakov O, Nabhitabhata J. 2018. Genus-level phylogeny of cephalopods using molecular markers: current status and problematic areas. PeerJ 2018:1-19. DOI: 10.7717/peerj.4331

Schneider B, Schmittner A. 2006. Simulating the impact of the Panamanian seaway closure on ocean circulation, marine productivity and nutrient cycling. Earth and Planetary Science Letters 246:367-380. DOI: 10.1016/j.eps1.2006.04.028

Stone, R. 2014. Battle for the Americas. Science 341:230-233. DOI: 10.1126/science.341.6143.230

Strugnell J, Jackson J, Drummond AJ, Cooper A. 2006. Divergence time estimates for major cephalopod groups: evidence from multiple genes. Cladistics 22:89-96. DOI: 10.1111/j.1096-0031.2006.00086.x

Strugnell JM, Rogers AD, Prodöhl PA, Collins MA, Allcock AL. 2008. The thermohaline expressway: The Southern Ocean as a centre of origin for deep-sea octopuses. Cladistics

Peer] reviewing PDF | (2019:06:38484:2:0:NEW 20 Jan 2020) 
638

639

640

641

642

643

644

645

646

647

648

649

650

651

652

653

654

655

656

657

658

659

660

661

662

663

664

665

666

667

668

669

670

671

672

673

24:853-860. DOI: 10.1111/j.1096-0031.2008.00234.x

Tamura K, Stecher G, Peterson D, Filipski A, Kumar S. 2013. MEGA6: Molecular evolutionary genetics analysis version 6.0. Molecular Biology and Evolution 30:2,725-2,729. DOI: $10.1093 / \mathrm{molbev} / \mathrm{mst} 197$

Voight JR. 1988. Trans-Panamanian geminate octopods (Mollusca:Octopoda). Malacologia 29:289-294.

Voss GL. 1981. A redescription of Octopus ornatus Gould, 1852 (Octopoda: Cephalopoda) and the status of Callistoctopus Taki, 1964. Proceedings of the Biological Society of Washington 94:525-534.

Werner R, Hoernle K, Bogaard P Van Den, Ranero C, Huene R Von, Korich D. 1999. Drowned 14-m.y.-old Galápagos archipelago off the coast of Costa Rica: implications for tectonic and evolutionary models. Geology 27:499-502. DOI: 10.1130/0091-7613(1999)027<0499

Yu Y, Harris AJ, Blair C, He X. 2015. RASP (Reconstruct Ancestral State in Phylogenies): a tool for historical biogeography. Molecular Phylogenetics and Evolution 87:46-49. DOI: 10.1016/j.ympev.2015.03.008

(1)

(1)

(1)

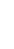

(1)


674 respective probabilities. EP $=$ Eastern Pacific; $\mathrm{WP}=$ Western Pacific; WA = Western Atlantic;

$675 \mathrm{Ma}=$ millions of years ago; $\mathrm{BBM}=$ Bayesian Binary Method; HPD $=$ Highest Posterior Density.

676

677 Figure 1 Localities of the specimens used in this study to estimate phylogenetic

678 relationships and divergence times among octopods species. Orange circles represent species

679 from the Eastern Pacific, blue circles those from the Western Atlantic, green circles those from

680 the Eastern Atlantic and yellow circles those from the Western Pacific. The Isthmus of Panama.

681

682 Figure 2 Integrated Bayesian phylogenetic tree and reconstruction of ancestral state. The

683 Bayesian posterior probabilities of the clades are shown below the nodes. Pie charts show the

684 posterior probabilities of ancestral areas on different nodes. The five clades discussed in this

685 study are highlighted in the phylogeny. The transisthmian sister species pair/complex are

686 indicated by an asterisk in clades 1, 3 and 5. The grey area represents the interval of divergence

687 time found in octopod species (5.22-17.24). The circles surrounding some pie charts on the

688 nodes indicate vicariance events. The graph shows events of dispersal and vicariance (axis y)

689 assigned to a time frame as a result of a modified Gaussian distribution. Vampyroteuthis

690 infernalis is not shown on this figure due to its long branch length (see Figure S1).

691

692 Supplemental information

693 Figure S1 Bayesian phylogenetic tree including all cephalopods species used in this study.

694 The bars on the nodes represent the 95\% Highest Posterior Density intervals. The 95\% HPD of

695 calibrated nodes with three fossils information are shown in orange bars. The asterisk represents

696 the biogeographical calibration. The mean ages of clades divergence are placed below each node

697 (Ma).

698 Table S1 Details of the specimens for COI, 16S rDNA, Rhodopsin and EF1-alpha genes

699 used to construct the final Bayesian phylogenetic tree in this study. GB = GenBank accession

700 number; $M O R G=$ Museu Oceanográfico do Rio Grande; $C T R=$ Coleção de tecidos de

701 invertebrados da UFRN. 
Figure 1

Localities of the specimens used in this study to estimate phylogenetic relationships and divergence times among octopods species.

Orange circles represent species from the Eastern Pacific, blue circles from the Western Atlantic, green circles from the Eastern Atlantic, and yellow circles are species from the Western Pacific. The Isthmus of Panama.

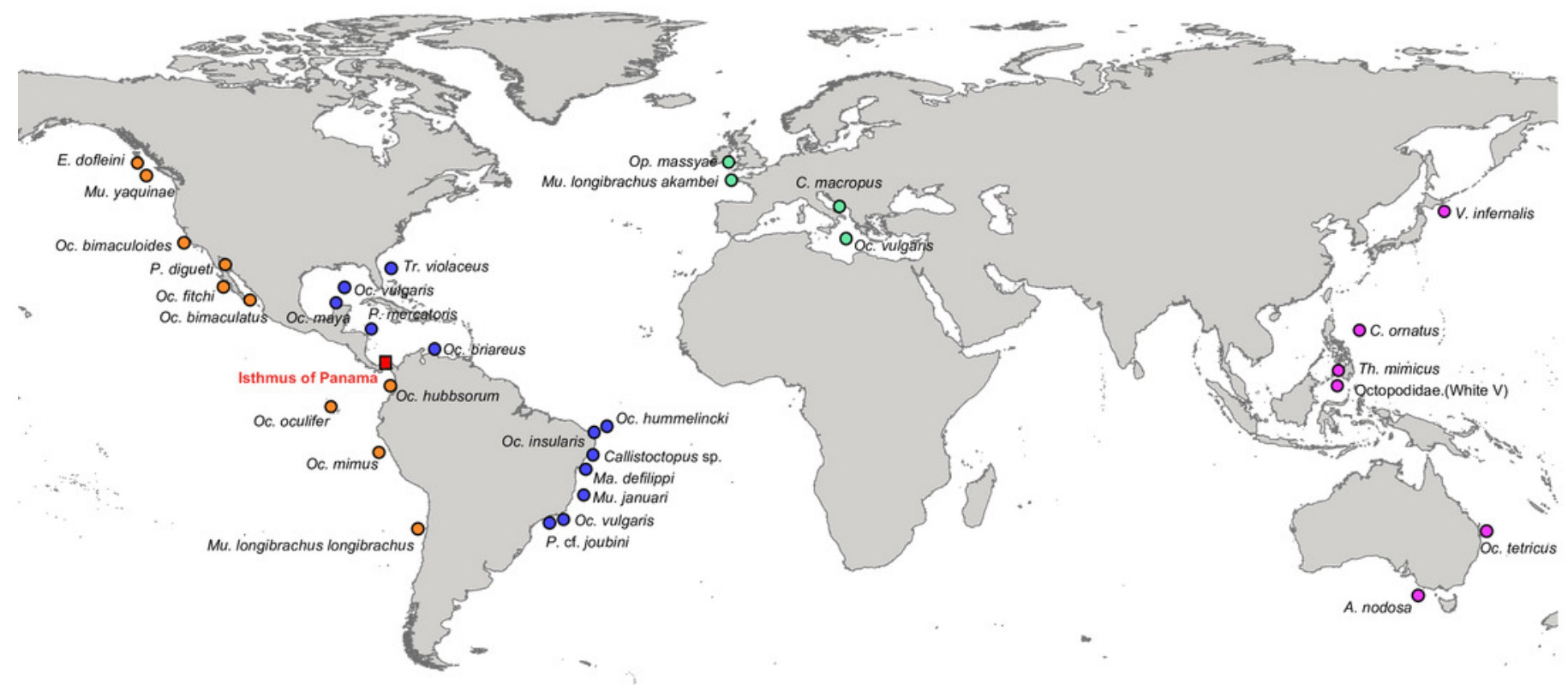




\section{Figure 2}

Integrated Bayesian phylogenetic tree and reconstruction of ancestral state.

The Bayesian posterior probabilities of the clades are shown below the nodes. Pie charts show the posterior probabilities of ancestral areas on different nodes. The five clades discussed in this study is highlighted in the phylogeny. The transisthmian sister species pair/complex are indicated by an asterisk in the clades 1, 3 and 5. Gray area represents the interval of divergence time found in octopod species (5.22 - 17.24). The circles surrounding some pie charts on the nodes indicate vicariance events. The graph shows events of dispersal and vicariance (axis y) assigned to a time frame as a result of a modified Gaussian distribution. Vampyroteuthis infernalis is not shown on this figure due to its long branch length (see Fig. S1). 
Wide range

Western Atlantic Eastern Atlantic

Western Pacific Eastern Pacific

Vicariance event
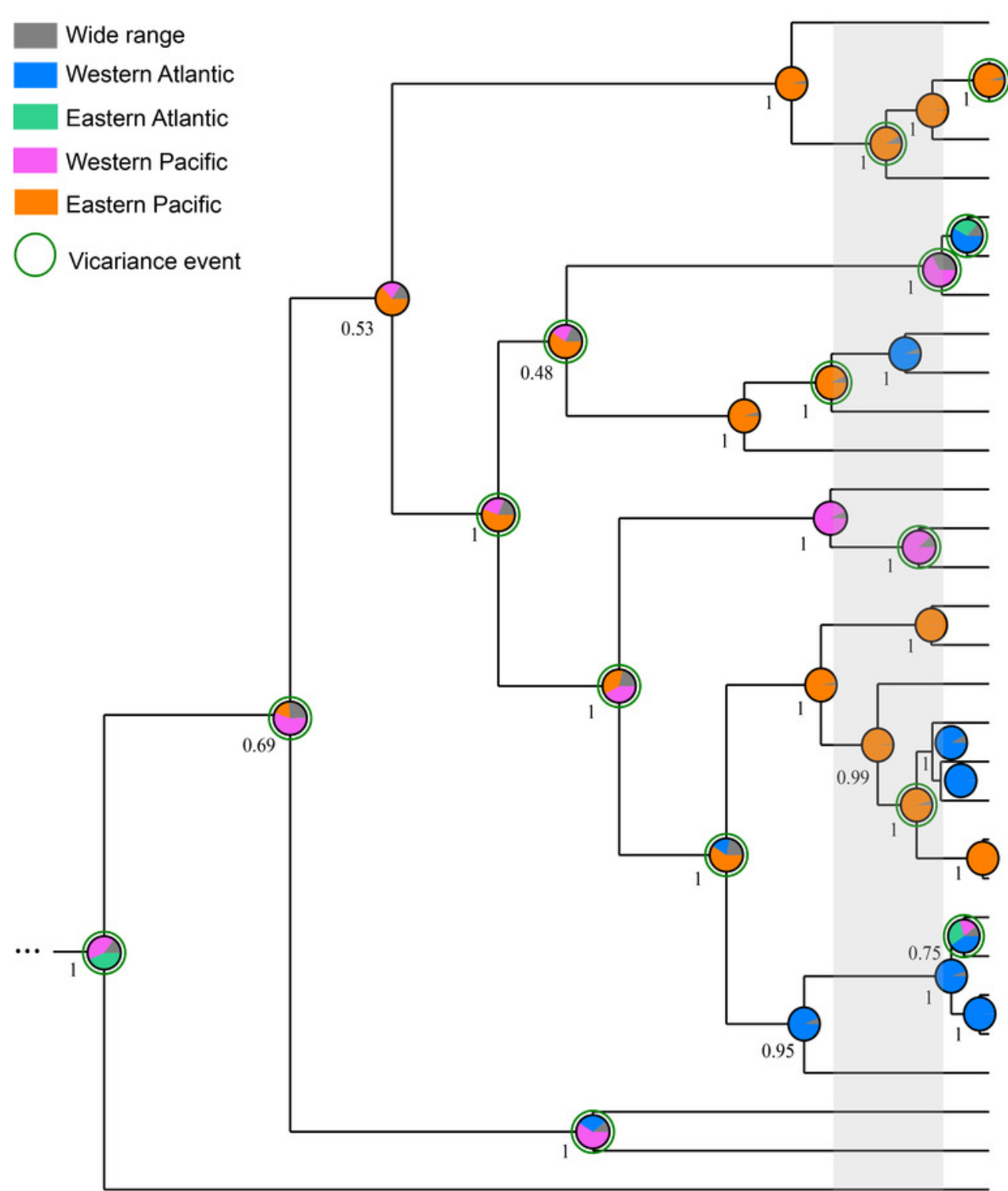

12

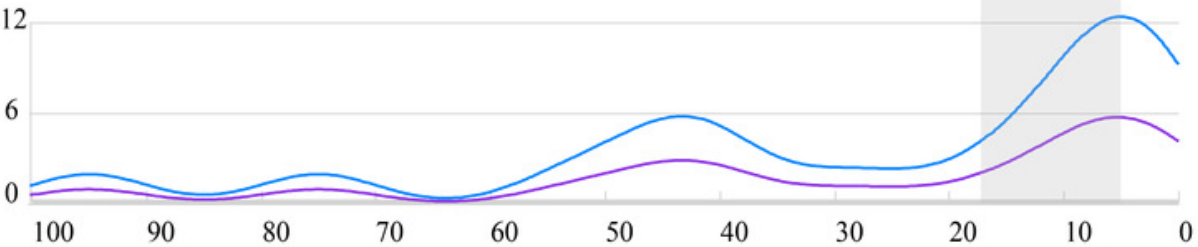

Divergence time (Ma)
Enteroctopus dofleini

Muusoctopus longibrachus akambei Muusoctopus longibrachus longibrachus Muusoctopus yaquinae

Muusoctopus januari ${ }^{\star}$ Clade 1 Callistoctopus sp.

Callistoctopus macropus

Callistoctopus ornatus

Clade 2

Paroctopus cf. joubini

Paroctopus mercatoris

Paroctopus digueti

${ }^{*}$ Clade 3

Octopus fitchi

Thaumoctopus mimicus

Octopodidae sp.(White V)

Macrotritopus defilippi

Clade 4

Octopus bimaculatus

Octopus bimaculoides

Octopus cf. oculifer

Octopus maya

Octopus hummelincki

Octopus insularis

Octopus mimus

Octopus hubbsorum

${ }^{*}$ Clade 5

Octopus vulgaris

Octopus tetricus

Octopus vulgaris

Octopus vulgaris

Octopus briareus

Tremoctopus violaceus

Argonauta nodosa

Opisthoteuthis massyae

\section{Dispersal}

Vicariance 


\section{Table $\mathbf{1}$ (on next page)}

Details of fossil and biogeographical information used to calibrate the phylogeny.

The prior probability distributions and posterior probability densities after the Monte Carlo

Markov Chain (MCMC) run are showed. $\mathrm{Ma}=$ millions of years ago, $\mathrm{Cl}=$ confidence interval, HPD = Highest Posterior Density . 
1 Table 1 Details of fossil and biogeographical information used to calibrate the phylogeny. The prior 2 probability distributions and posterior probability densities after the Monte Carlo Markov Chain (MCMC) run 3 are showed. $\mathrm{Ma}=$ millions of years ago, $\mathrm{Cl}=$ confidence interval, $\mathrm{HPD}=$ Highest Posterior Density. 4

\begin{tabular}{|c|c|c|c|c|c|c|c|}
\hline \multirow{2}{*}{$\begin{array}{l}\text { Calibration } \\
\text { node }\end{array}$} & \multirow{2}{*}{$\begin{array}{l}\text { Distribu } \\
\text { tion }\end{array}$} & \multirow{2}{*}{ Type } & \multicolumn{3}{|c|}{ Prior (Ma) } & \multirow{2}{*}{$\begin{array}{l}\begin{array}{l}\text { MCMC } \\
(\mathrm{Ma})\end{array} \\
\text { Mean }\end{array}$} & \multirow{2}{*}{$\begin{array}{l}\text { results } \\
95 \% \\
\text { HPD }\end{array}$} \\
\hline & & & $\begin{array}{l}\text { Me } \\
\text { an }\end{array}$ & $\begin{array}{l}\text { Off } \\
\text { set }\end{array}$ & $95 \% \mathrm{Cl}$ & & \\
\hline $\begin{array}{l}\text { M. longibrachus } \\
\text { akambei x M. } \\
\text { longibrachus } \\
\text { longibrachus }\end{array}$ & Normal & $\begin{array}{l}\text { Biogeograp } \\
\text { hical }\end{array}$ & $\begin{array}{l}0.0 \\
25\end{array}$ & - & $\begin{array}{l}0.015 \\
0.035\end{array}$ & 0.032 & $\begin{array}{l}0.024 \\
0.04\end{array}$ \\
\hline $\begin{array}{l}\text { Argonauta } \\
\text { nodosa } \\
\text { Tremoctopus } \\
\text { violaceus }\end{array}$ & $\begin{array}{l}\text { Exponen } \\
\text { tial }\end{array}$ & Fossil & 35 & 29 & 30,62 & 46 & 29,68 \\
\hline $\begin{array}{l}\text { Cirrata } \quad x \\
\text { Incirrata }\end{array}$ & $\begin{array}{l}\text { Exponen } \\
\text { tial }\end{array}$ & Fossil & 25 & 90 & 95,187 & 101 & 90,121 \\
\hline $\begin{array}{l}\text { Vampyromorph } \\
\text { a x Octopoda }\end{array}$ & $\begin{array}{l}\text { Exponen } \\
\text { tial }\end{array}$ & Fossil & 24 & 162 & 162,250 & 170 & $\begin{array}{l}162 \\
187\end{array}$ \\
\hline
\end{tabular}




\section{Table 2 (on next page)}

Divergence time estimates for each clade containing transisthmian sister species pair/complex.

The events of dispersal and vicariance are shown for each clade. The possible routes of dispersal for the most recent common ancestor in each clade are also shown with their respective probabilities. EP $=$ Eastern Pacific, WP $=$ Western Pacific, WA $=$ Western Atlantic, $\mathrm{Ma}=$ millions of years ago, BBM $=$ Bayesian Binary Method, $\mathrm{HPD}=$ Highest Posterior Density. 
1 Table 2 Divergence time estimates for each clade containing transisthmian sister species 2 pair/complex. The events of dispersal and vicariance are shown for each clade. The possible routes of 3 dispersal for the most recent common ancestor in each clade are also shown with their respective 4 probabilities. EP $=$ Eastern Pacific, $W P=$ Western Pacific, $W A=$ Western Atlantic, $M a=$ millions of years 5 ago, BBM = Bayesian Binary Method, HPD = Highest Posterior Density.

6

\begin{tabular}{lllllll}
\hline \multirow{2}{*}{ Clade } & \multicolumn{2}{l}{ Divergence time (Ma) } & $\begin{array}{l}\text { Vicariance } \\
\text { event }\end{array}$ & $\begin{array}{l}\text { Dispersal } \\
\text { event (N) }\end{array}$ & BBM Route & BBM Probability \\
\cline { 2 - 5 } & Mean & $\mathbf{9 5 \%}$ HPD & & 2 & EP->WA & 0.8801 \\
\hline 1 & 11.39 & $5.08,20.77$ & 1 & 2 & WP->WA & 0.3678 \\
2 & 5.22 & $2.21,10.96$ & 1 & 2 & EP->WA & 0.8745 \\
3 & 17.24 & $8.99,30.31$ & 1 & 2 & WP->WA & 0.8771 \\
4 & 7.83 & $2.82,15.88$ & 1 & 2 & EP->WA & 0.8739 \\
5 & 8.03 & $4.27,13.58$ & 1 & & &
\end{tabular}

7 